\author{
ANNA KAPUŚCIŃSKA \\ Uniwersytet Kazimierza Wielkiego w Bydgoszczy \\ Katedra Germanistyki
}

\title{
Lubię to! Neosemantyzacja leksemu lubić w kontekście Facebooka
}

Słowa klucze: ekwiwalencja; neosemantyzacja; ewolucja języka; uzus; media

Ke y words: equivalence; neosemantisation; language evolution; language usage; media

\section{Wstęp}

Wraz z pojawieniem się polskiej wersji portalu społecznościowego Facebook, leksem lubić zaczął być używany w nowym znaczeniu1. Jak zauważa na swojej stronie jeden z internautów: „lubimy obrazki i filmiki, które pierwszy raz widzimy. Lubimy też aplikacje i strony firm i produktów, często dlatego, że musimy je polubić żeby wejść dalej, skorzystać z promocji lub wziąć udział w konkursie. Często mówią nam to wprost: Żeby zrobić to musisz polubić tamto" (Ochałek 2011, http://kiepskiechocpolskie.pl).

Celem niniejszego artykułu jest refleksja nad zjawiskiem neosemantyzacji leksemu lubić we frazie „Lubię to!” oraz frazach pochodnych w kon-

1 Bugajski podkreśla, iż główną przyczyną zmian w polszczyźnie w ostatnich latach są czynniki zewnętrzne (Bugajski 2010: 136). Za najważniejszy z nich uważa - za Bajerową (1980) - technikę (por. Bugajski 2010: 136; Bugajski 2007: 311). 
tekście portalu społecznościowego Facebook, poparta analizą sposobów ich funkcjonowania na przykładzie stron internetowych wybranych szkół wyższych.

\section{Neosemantyzacja leksemu lubić na Facebooku}

Należy podkreślić, iż zjawisko to jest swego rodzaju fenomenem co najmniej z dwóch powodów. Po pierwsze neosemantyzmy, czyli wyrazy już istniejące, którym nadano nowe znaczenie (por. Słownik języka polskiego 1995: 764; Pisarek 2006: 128) powstaja zwykle dla zapełnienia tzw. ,luk leksykalnych" ${ }^{2}$. Jako przykłady takich neosemantyzmów wymieniane są m. in. leksemy: adres, folder, forum, ikona, modut, mysz, okno, platforma, plik, portal, sieć, tapeta, wirus oraz witryna (por. Michajłow 2011: 212; Zabawa 2009: 75; Data 2009: 135) ${ }^{3}$. Powstanie neologizmu lubić nie wynikało z braku znaku językowego dla określenia nowego elementu rzeczywistości. W analizowanym wypadku pojawił się jedynie nowy kontekst, w którym istniejący już element rzeczywistości występuje. Po drugie, neosemantyzacja rzadko dokonuje się tak dynamicznie i w tak krótkim czasie, zważywszy na fakt, iż polska wersja portalu ruszyła w 2008 roku (por. Rusza polska wersja Facebooka 2008, http://www.wirtualnemedia.pl).

Proces neosemantyzacji leksemu lubić można podzielić na co najmniej trzy etapy. Pierwszy z nich to neosemantyzacja dokonana podczas thumaczenia tekstu portalu na język polski, w wyniku którego angielskie I like it przetłumaczono jako Lubię to!, a nie jako (wydawałoby się „,bardziej” ekwi-

2 Termin ten stosuje m. in. Żmigrodzki w artykule Z leksykograficznej listy nieobecności: przymiotnik ocenny (por. Żmigrodzki 2007: 103-111).

3 Są to przykłady neosemantyzmów, w których nabyte znaczenie jest węższe od wcześniej posiadanego znaczenia (lub wcześniej posiadanych znaczeń). Można jednak wskazać również przykłady sytuacji odwrotnej, gdy nowe znaczenie jest szersze od znaczenia wcześniejszego, funkcjonującego głównie w języku fachowym. Zalicza się do nich leksem logowanie, oznaczający dotąd 'podłączenie się do Internetu'. Dziś, jak zauważa Borowski, leksem ten stał się synonimem leksemu wejść, wskutek czego „zalogować można się praktycznie wszędzie - zarówno na prywatkę, jak i do czyjegoś domu" (Borowski 2002: 26; cyt. za Michajłow 2011: 211). Bugajski wskazuje na podobne przykłady neosemantyzacji leksemów występujących w językach fachowych innych niż język komputerowy. Są to takie leksemy, jak: ,wentyl bezpieczeństwa, dodać gazu, aparat (człowiek w jakiś sposób się wyróżniający), robić coś automatycznie (odruchowo), mieć opóźniony zapłon (o kimś powolnym)" (Bugajski 2007: 318). 
walentne) Podoba mi się. Dwa pozostałe etapy to neosemantyzacja, która miała miejsce już podczas użytkowania polskiej wersji językowej portalu, paralelna do tej, zachodzącej w wersji oryginalnej. Lubię to! bywa bowiem stosowane albo w znaczeniu 'jestem z tym związany"4, gdy np. oznacza się w ten sposób swoją uczelnię lub firmę, której jest się stałym klientem, albo też w znaczeniu 'polecam', gdy lubi się jakiś produkt lub usługodawcę, nierzadko w celu uzyskania wymiernych korzyści.

\section{Lubię to! jako 'podoba mi się'}

W języku angielskim czasownik like posiada dwa znaczenia: to find $s b /$ sth pleasant, attractive or satisfactory; to enjoy sth oraz to prefer to do sth; to prefer sth to be made or to happen in a particular way (Oxford Advanced Learner's Dictonary 2000: 745). W polskim systemie językowym nie występuje czasownik będący ekwiwalentem w relacji 1:1 dla angielskiego like. Każdemu z obu znaczeń odpowiada w języku polskim inny czasownik. W zależności od tego, które znaczenie przypisze się zwrotowi I like it, można je interpretować odpowiednio jako Podoba mi się to lub Lubię to.

Sam założyciel portalu społecznościowego Facebook Mark Zuckerberg, tworząc opcję I like it, najprawdopodobniej miał na myśli to pierwsze znaczenie. Może o tym świadczyć chociażby piktogram towarzyszący komunikatowi tekstowemu. Zarówno w Stanach Zjednoczonych, jak również w znacznej części Europy gest podniesionego kciuka jest wyrazem raczej aprobaty, niż sympatii. Mimo to, jak wiadomo, podczas tłumaczenia na język polski, fraza I like it została przetłumaczona jako Lubię to!, choć np. w języku niemieckim - gdzie ekwiwalencja czasownika like jest podobna jak w języku polskim widnieje w tym miejscu Gefällt mir, czyli po polsku Podoba mi się.

Należałoby zadać pytanie, skąd decyzja osób tłumaczących tekst portalu na język polski, aby mimo to nazwać słynny przycisk Lubię to!. Zważywszy na fakt, iż tłumaczenia na język polski podjęło się społecznie ponad 450 polskojęzycznych użytkowników (por. Rusza polska wersja Facebooka 2008, http://www.wirtualnemedia.pl), można byłoby uzasadnić takie tłumaczenie ich niekompetencją. Bardziej prawdopodobne jest jednak, iż frazę $\mathrm{Lu}$ -

4 Ponieważ niezbyt często zdarza się, aby sam fakt znajomości czegoś był przyczyną „lubienia” tego na Facebooku, takie objaśnienie frazy Lubię to! w tym znaczeniu wydaje się trafniejsze, niż proponowane przez Dybek - znać (por. Dybek 2011: 13). 
bię to! z pewnych względów uznano za bardziej atrakcyjną niż Podoba mi się, zwłaszcza że przełożone frazy zostały potem zatwierdzone droga głosowania przez resztę użytkowników (por. Rusza polska wersja Facebooka 2008, http:// www.wirtualnemedia.pl).

Należy również pamiętać, że z facebookowym I like it związane są również frazy pochodne, takie jak np. „(liczba) people like (nazwa strony)”, informująca, ile osób lubi daną stronę na Facebooku lub Like us on Facebook, zachęcająca do dołączenia do grona osób „lubiących”. We wszystkich tych wyrażeniach jest obecny czasownik like. O ile w niemieckiej wersji portalu spójność semantyczna nie została zachowana, w działaniach osób tłumaczących polską wersję wyraźnie widać tendencję odwrotną. Podobnie jak w oryginale, we wszystkich tych wyrażeniach występuje czasownik like, tak w ich polskich odpowiednikach: (liczba) osób lubi (nazwa strony) oraz Polub nas na Facebooku wspólny jest czasownik lubić. Dodatkowo w przypadku drugiego wyrażenia czasownik lubić występuje w trybie rozkazującym, choć w języku polskim na ogół nie stosuje się formy trybu rozkazującego dla czasowników modalnych, do których czasownik ten zwykle się zalicza. Gdyby zdecydowano się na tłumaczenie I like it jako Podoba mi się, dla zachowania spójności należałoby przetłumaczyć te frazy jako „(liczba) osobom podoba się (nazwa strony)" oraz Niech Ci sie spodobamy na Facebooku. Zwłaszcza to drugie wyrażenie byłoby wówczas znacznie bardziej złożone, a przez to mniej atrakcyjne pod względem marketingowym.

Warto też zauważyć, iż sposób w jaki przetłumaczono frazę I like it na język polski umożliwił zachowanie rytmu frazy oryginalnej. Dla porównania warstwa rytmiczna nie została również zmieniona w niemieckiej wersji, co może świadczyć o tym, iż zachowanie ekwiwalentnego rytmu było istotnym kryterium uwzględnianym przy tłumaczeniu.

Niezależnie od motywacji, osoby tłumaczące przyczyniły się do powstania neologizmu semantycznego. Czasownik lubić nabrał bowiem dodatkowego znaczenia, analogicznie do angielskiego like.

\section{Lubię to! jako 'jestem z tym związany'}

Jak nietrudno zauważyć, facebookowe Lubię to! nie zawsze wyraża stosunek emocjonalny. Są liczne przypadki, gdy owo „lubienie” wyraźnie wykracza zarówno poza tradycyjne pole semantyczne polskiego czasownika $l u$ - 
bić, jak i (bardziej pojemnego znaczeniowo) angielskiego czasownika like. Jak podaje Dybek (2011: 13): „(o) godz. 18 (nadal środa) Marka Zuckerberga 'lubi' już 3.011.557 osób. Mimo, że on sam na serwisie ujawnia się rzadko.' Naturalnie nie jest możliwe, aby w tym przypadku Lubię to! było wyrazem sympatii, gdyż zdecydowana większość „lubiących” nie miała nawet okazji korespondować z twórcą Facebooka. Bardziej prawdopodobne jest, iż lubię w tym przypadku oznacza 'jestem z tym związany', a w związku z tym 'interesuje mnie to, chcę to obserwować'. Tak więc użytkownicy odczuwają swego rodzaju związek z Markiem Zuckerbergiem, jako twórcą portalu, z którego korzystają.

Podobne znaczenie posiada fraza Lubię to! w przypadku instytucji, z którymi użytkownik jest związany. Informacja, że np. 1000 osób „lubi” daną firmę nie oznacza więc, że świadczone przez nią usługi są bardziej cenione niż usługi świadczone przez konkurencyjną firmę, którą „lubi” 500 osób. Może to oznaczać jedynie, że firma o większej popularności na Facebooku posiada więcej klientów lub że większa liczba klientów trafiła na konto tej firmy na portalu 5 .

Można wymienić co najmniej dwie korzyści z nadawania oznaczenia $\mathrm{Lu}$ bię to! w takim znaczeniu. Po pierwsze tylko „lubiący” mają możliwość śledzenia aktualnych wpisów dotyczących danego obiektu ${ }^{6}$. Po drugie zaś „lubienie" czegoś, co lubią inni, daje użytkownikowi poczucie przynależności, co stanowi jedną z podstawowych funkcji każdego portalu społecznościowego. Służy temu chociażby podawanie liczby „lubiących” oraz wyświetlanie miniatur zdjęć losowo wybranych spośród nich osób. Niekiedy apel obok tradycyjnego symbolu podniesionego kciuka z tekstem Lubię to! nie brzmi Polub nas na Facebooku, lecz Dołacz do nas na Facebooku, co dodatkowo podkreśla aspekt wspólnotowy „lubienia”.

Jak uważa Pete Cashmore z serwisu Mashable, również decyzja o niedodawaniu wbrew licznym głosom internautów przycisku Nie lubię tego

5 Hipoteza taka zakłada, iż wszystkie kliknięcia w Lubię to! oznaczają rzeczywisty związek z daną firmą. Nie można jednak wykluczyć, że przynajmniej część z nich jest wynikiem działań marketingowych firmy, polegających np. na oferowaniu wymiernych korzyści w zamian za „lubienie”.

${ }^{6}$ Ponieważ „lubienie” może odnosić się zarówno do firm i instytucji, jak również do artykułów, zdjęć, plików dźwiękowych i innych, uzasadnione wydaje się stosowanie w artykule dla ich określania hiperonimu obiekt. Ze względu na różny charakter obiektów, można mówić o obiektach instytucjonalnych oraz obiektach intelektualnych. 
jest motywowana społecznościowym charakterem portalu. Jego zdaniem, „przycisk 'lubię to' sprzyja nawiązywaniu kontaktów, co jest bardzo istotne dla powiększania liczby użytkowników. 'Nie lubię tego' skłania raczej do zrywania więzi i właściwie nie wnosi niczego dobrego (Nowak 2011, http://di.com.pl)"7.

Wprowadzenie przycisku Nie lubię tego byłoby również nieuzasadnione ze względów semantycznych. W związku z interpretacją przycisku Lubie to! jako 'Jestem z tym związany', przycisk Nie lubię tego poprzez opozycję oznaczałby jedynie, iż użytkownik nie odczuwa żadnego związku z obiektami oznaczonymi przez niego tym przyciskiem.

\section{Lubię to! jako 'Polecam'}

Często zdarza się także stosowanie przycisku Lubię to! w odniesieniu do obiektów, z którymi użytkownik nie czuje się w żaden sposób związany. Wydaje się, że „lubienie” jako ‘polecanie’ można podzielić na dwa typy, z których pierwszy ma charakter niekomercyjny, a drugi komercyjny.

Polecanie niekomercyjne ma zwykle miejsce, gdy obiekt instytucjonalny na swojej stronie internetowej zachęca do ,polecenia” go na Facebooku, choć nie oferuje w zamian żadnej wymiernej korzyści. Zdarza się, że obiekt daje wprost do zrozumienia, iż chodzi o to, aby użytkownik go polecił. Wówczas tekst apelatywny zamiast tradycyjnego Polub nas na Facebooku, brzmi Poleć nas na Facebooku. Również tutaj często wykorzystuje się poczucie przynależności, wyświetlając liczbę osób, które polecają dany obiekt, niekiedy wraz z miniaturami zdjęć profilowych.

Inny mechanizm można zaobserwować w sytuacji, gdy dany obiekt nie jest jeszcze przez nikogo polecany. Wówczas często pojawia się apel Badź pierwszym znajomym, który to lubi. Komunikat taki wyraźnie zachęca, aby nie dać się wyprzedzić innym, którzy z pewnością niezwłocznie „polubiliby” stronę tego obiektu, gdyby tylko natknęli się na nią w Internecie.

Motywacja do niekomercyjnego ,polecania” może być różna i w znacznym stopniu jest związana z typem obiektu. „Lubienie” może mieć na celu

7 Decyzja o niewprowadzaniu opcji Nie lubię tego jest również uzasadniana $\mathrm{m}$. in. faktem, że mogłoby to „godzić w interesy właścicieli stron, którzy na swoich witrynach umieszczają dodatki dla deweloperów serwowane przez Facebooka" (Nowak 2011, http:// di.com.pl). 
chociażby wyrażenie wdzięczności wobec twórców strony, np. Znalazłeś tu pracę? Poleć nas na Facebooku (Job-broker.pl, http://wroclaw.job-jumper.pl).

Drugi typ ,polecania” ma charakter wyraźnie komercyjny. Wiele firm zachęca: Polub nas na Facebooku i wygraj iPoda! (Wałbrzych fakty, http://walbrzychfakty.pl), Polub nas na Facebooku i wygraj zestaw kosmetyków Pharmaceris! (Rodzinny Kraków, http://www.rodzinny-krakow.pl), Polub nas na Facebooku i zgarnij nagrodę (Simplik, http://www.simplik.pl/konkurs.php). „Polubienie” danego obiektu jest więc przepustką do otrzymania darmowego upominku, rabatu bądź wzięcia udziału w konkursie.

\section{6. „Lubienie” szkół wyższych}

Zdaniem badaczy przycisk Lubię to!, jako wtyczka portalu Facebook, przyczynia się do znacznego wzrostu ruchu na stronie, „nawet o 190\% w przypadku ABC News, 200\% w przypadku Gawkera, 200\% w przypadku TypePada, 500\% w przypadku Sporting News" (Szpunar 2010, http://www. idg.pl). Nic zatem dziwnego, że można znaleźć go na stronach internetowych obiektów instytucjonalnych należących do niemal każdej branży. Przeprowadzona analiza dotyczy jego występowania na stronach szkół wyższych. Materiał badawczy obejmuje 34 strony internetowe, należące zarówno do państwowych, jak i niepaństwowych uczelni zlokalizowanych w Warszawie. Wybór lokalizacji był podyktowany względami kwantytatywnymi.

Analizie zostały poddane elementy związane z Facebookiem występujące na stronach internetowych. W przypadkach, gdy na jednej stronie znajdowało się więcej niż jedno odniesienie do Facebooka, uwzględniany był tylko fakt występowania poszczególnych elementów, nie zaś ich ilość. W przypadku przycisku Lubię to! pod uwagę brano tylko przyciski odnoszące się do danej uczelni, nie zaś przyciski przy każdej z informacji podanej na stronie. Poniższa tabela przedstawia wyniki przeprowadzonej analizy. 
Tabela 1. Występowanie elementów odnoszących się do portalu Facebook na stronach internetowych uczelni w Warszawie

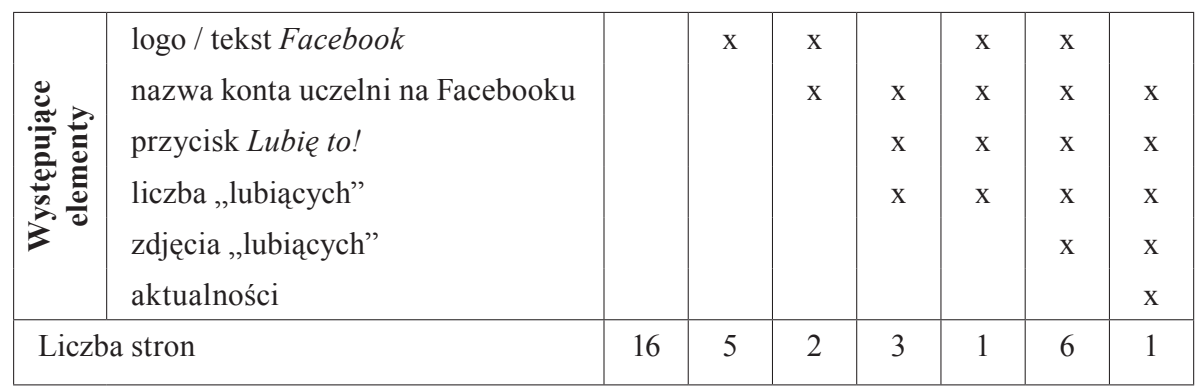

Jak wynika z przeanalizowanego materiału, elementy odnoszące się do Facebooka nie występują na stronach 16 uczelni (ok. 47\%), a występują na stronach łącznie 18 uczelni (ok. 53\%).

Wśród stron zawierających wspomniane odnośniki pięć to takie, gdzie mają one postać jedynie znaku graficznego Facebooka w postaci całego wyrazu lub tylko litery „f”. Może on występować pojedynczo lub wśród symboli innych portali społecznościowych. W tym drugim wypadku bywa poprzedzony komunikatem apelatywnym, np. Podażaj za nami na:, który jednak nie odnosi się tylko do Facebooka, lecz do wszystkich widniejących na stronie portali społecznościowych.

Kolejna grupa, do której należą dwie z analizowanych stron, to te, na których nazwie portalu (w postaci znaku graficznego, tekstu pisanego bądź też w obu tych postaciach) towarzyszy nazwa konta danego obiektu na Facebooku (Wyższa Szkoła Informatyki Stosowanej i Zarzqdzania na Facebooku oraz - w języku angielskim - ALMAMER on Facebook).

Omówione przykłady to typowe odnośniki mające postać elementu graficznego lub tekstu pisanego. Inną formą występowania elementów związanych z Facebookiem na stronach internetowych są przyciski Lubię to!. Przycisk taki może występować osobno wraz z symbolem graficznym Facebooka i liczbą ,lubiących” (trzy strony) lub w postaci bardziej rozbudowanych wtyczek. W jednym przypadku wtyczka zawiera nazwę portalu Facebook, nazwę konta obiektu na Facebooku (w postaci tekstu Wyższa Szkoła Zarzadzania Personelem na Facebooku), przycisk Lubię to! oraz liczbę osób „lubiących”. W sześciu innych przypadkach oprócz tych elementów występują również zdjęcia niektórych osób „lubiących”. Ponadto w jednej wtyczce oprócz na- 
zwy konta, przycisku Lubię to!, liczby „lubiących” oraz zdjęć wprowadzono przegląd aktualności dotyczących uczelni, do której to konto należy.

Przeprowadzona analiza materiału badawczego umożliwiła sformułowanie następujących wniosków:

1. Występowanie odniesień do Facebooka na stronach internetowych uczelni nie jest powszechne. W analizowanym materiale występują one tylko na $53 \%$ stron.

2. Na analizowanych stronach czasownik lubić występuje we frazie Lubie to! oraz w wyrażeniu Liczba osób, które lubiq (nazwa strony) na Facebooku: Nie zdarzają się natomiast inne wyrażenia, spotykane w przypadku innych obiektów, jak np. Polub nas na Facebooku.

3. Frazę Lubię to! w przypadku stron uczelni należy rozumieć jako 'jestem z tym związany’. Można przypuszczać, że większość osób „lubiących” daną uczelnię to jej studenci, absolwenci oraz pracownicy. W materiale badawczym nie wystąpił żaden przypadek nakłaniania do polecenia uczelni poprzez jej „lubienie”.

\section{Podsumowanie}

Choć nowe znaczenia czasownika lubić nie weszły do słownika języka polskiego ani nie są stosowane w kontekstach niezwiązanych z Facebookiem, niezaprzeczalnym faktem jest, że portal ten dokonał czegoś, co wydawało się niemożliwe - nadał jednemu z najpopularniejszych czasowników w języku polskim nowe właściwości semantyczno-syntaktyczne. Przypadek ten po pierwsze dowodzi, iż język nie jest konstruktem statycznym, lecz ewoluuje wraz ze zmieniającą się rzeczywistością, a po drugie obrazuje ogromną siłę oddziaływania Internetu.

\section{Wykaz źródeł uwzględnionych $w$ analizie}

Akademia Finansów [online], http://wsub.nazwa.pl/joomla/, [01.10.2011].

Akademia Leona Koźmińskiego [online], http://www.kozminski.edu.pl/index.php/ $\mathrm{pl} /,[01.10 .2011]$.

ALMAMER Szkoła Wyższa [online] <http://www.almamer.pl/index.php>, dostęp: 01.10.2011.

Collegium Civitas [online], http://www.civitas.edu.pl/, [01.10.2011]. 
Dobra Uczelnia [online], http://www.dobrauczelnia.pl/sg/, [01.10.2011].

Europejska Wyższa Szkoła Prawa i Administracji [online], http://www.ewspa.edu.pl/ index.html, [01.10.2011].

Lingwistyczna Szkoła Wyższa w Warszawie [online], http://www.lingwistyka.edu. pl/Index, [01.10.2011].

Politechnika Warszawska [online], http://www.pw.edu.pl/index.php, [01.10.2011].

Szkoła Główna Straży Pożarniczej [online], http://www.sgsp.edu.pl/, [ 01.10.2011].

Szkoła Wyższa Przymierza Rodzin [online], http://www.swpr.edu.pl/index.php?zakladka=home, [01.10.2011].

Szkoła Wyższa Psychologii Społecznej [online], http://www.swps.pl/, [01.10.2011].

Szkoła Wyższa im. Bogdana Jańskiego [online], http://www.janski.edu.pl/, [01.10.2011].

Uczelnia Heleny Chodkowskiej [online], http://www.chodkowska.edu.pl/, [01.10.2011].

Uczelnia Łazarskiego [online], http://www.lazarski.pl/, [01.10.2011].

Uniwersytet Warszawski [online], http://www.uw.edu.pl/, [01.10.2011].

Warszawska Wyższa Szkoła Humanistyczna [online], http://www.asw.edu.pl/, [01.10. 2011].

Wojskowa Akademia Techniczna im. Jarosława Dąbrowskiego [online], http://www. wat.edu.pl/, [01.10.2011].

Wyższa Szkoła Cła i Logistyki [online], http://www.wscil.edu.pl/, [01.10.2011].

Wyższa Szkoła Dziennikarska im. Melchiora Wańkowicza [online], http://www.wsd. edu.pl/, [01.10.2011].

Wyższa Szkoła Edukacja w Sporcie [online], http://www.ews.edu.pl/, [01.10.2011].

Wyższa Szkoła Finansów i Zarządzania w Warszawie [online], http://www.vizja.pl/, [01.10.2011].

Wyższa Szkoła Gospodarowania Nieruchomościami [online], http://www.wsgn.pl/, [01.10.2011].

Wyższa Szkoła Handlu i Finansów Międzynarodowych im. Fryderyka Skarbka [online], http://www.wshifm.edu.pl/e4u.php/1, [01.10.2011].

Wyższa Szkoła Hotelarstwa, Gastronomii i Turystyki w Warszawie [online], http:// www.wshgit.waw.pl/, [01.10.2011].

Wyższa Szkoła Informatyki Stosowanej i Zarządzania [online], http://www.wit.edu. $\mathrm{pl} /$, [01.10.2011].

Wyższa Szkoła Infrastruktury i Zarządzania w Warszawie [online], http://www.wsiiz. $\mathrm{pl} /$, [01.10.2011].

Wyższa Szkoła Kultury Fizycznej i Turystyki [online], http://www.wskfit.pl/, [01.10. $2011]$.

Wyższa Szkoła Menadżerska w Warszawie [online], http://www.kaweczynska.pl/, [01.10.2011]. 
Wyższa Szkoła Organizacji Turystyki i Hotelarstwa w Warszawie [online], http:// www.wsotih.edu.pl/index.php/pl/, [01.10.2011].

Wyższa Szkoła Promocji [online], http://www.wsp.pl/, [01.10.2011].

Wyższa Szkoła Techniczno-Ekonomiczna w Warszawie FUTURUS [online], http:// www.wste.pl/, [01.10.2011].

Wyższa Szkołą Turystyki i Języków Obcych [online], http://www.wstijo.edu.pl/news. aspx, [01.10.2011].

Wyższa Szkoła Turystyki i Rekreacji im. Mieczysława Orłowicza [online], http:// www.wstir.edu.pl/, [01.10.2011].

Wyższa Szkoła Zarządzania Personelem [online], http://www.wszp.edu.pl/Strona glowna,1.html, [01.10.2011].

\section{Wykaz pozostałych źródel}

Job-broker.pl [online], http://wroclaw.job-jumper.pl/home/prywatnosc, [01.10.2011].

Rodzinny Kraków [online], http://www.rodzinny-krakow.pl/konkursy-dla-mam/Polubnas-na-Facebooku-i-wygraj-zestaw-kosmetykow-Pharmaceris.aspx, [01.11.2011].

Simplik [online], http://www.simplik.pl/konkurs.php, [01.11.2011].

Wałbrzych fakty [online], http://walbrzychfakty.pl/2011/04/28/polub-nas-na-facebooku-i-wygraj-ipoda-latwizna/, [01.10.2011].

\section{Bibliografia}

BAJerowa I., 1980, Wpływ techniki na ewolucje języka polskiego, Kraków: Wydawnictwo Polskiej Akademii Nauk.

Borowski J., CU, czyli do zobaczenia [online], http://www.wprost.pl/ar/8331/CU-czyli-do-zobaczenia/, [20.12.2012].

Bugajski M., 2007, Język w komunikowaniu, Warszawa: Wydawnictwo Naukowe PWN.

BugAJSKi M., 2010, Sytuacja komunikacyjna a zmiany językowe (rekonesans badawczy), w: G. Sawicka (red.), Sytuacja komunikacyjna i jej parametry, Bydgoszcz: Uniwersytet Kazimierza Wielkiego w Bydgoszczy, s. 134-145.

Data K., 2009, Wpływ komunikacji sieciowej na współczesną polszczyznę, w: D. Ulicka (red.), Tekst (w) sieci. Tekst. Język. Gatunki, Warszawa: Wydawnictwa akademickie i profesjonalne, s. 131-138.

Dybek A., 2011, Nie masz konta - nie istniejesz. Jak Facebook przyniósł majątek, Gazeta Pomorska, 18.09.2011, s. 12-13. 
MichaJŁow A., 2011, Język Internetu - nowy rytuał językowy oraz niektóre jego następstwa, w: M. Cieszkowski i J. Szczepaniak (red.), Język. Rytuat. Płeć. Prace Komisji Językoznawczej Bydgoskiego Towarzystwa Naukowego, Bydgoszcz, s. 207-218.

NowaK A., Facebook nie doda przycisku ,nie lubię” [online], http://di.com.pl/news/32782,0,Facebook_nie_doda_przycisku_nie_lubie.html, [01.10.2011].

Оснаєек M.,Nielubięlubić[online],http://kiepskiechocpolskie.pl/tag/internet/,[27.11. 2011].

Pisarek W., 2006, Stownik terminologii medialnej, Kraków: Universitas.

Rusza polska wersja Facebooka [online], http://www.wirtualnemedia.pl/artykul/rusza-polska-wersja-facebooka, [27.11.2011].

Sobol E. (red.), 1995, Stownik języka polskiego, Warszawa: Wydawnictwo Naukowe PWN.

SzPunAR W., Facebook: Lubię to zwiększy ruch w sieci [online], http://www.idg.pl/ news/362543/ facebook.lubie.to.zwieksza.ruch.w.sieci.html, [01.11.2011].

Wehmeier S. (red.), 2000, Oxford Advanced Learner's Dictonary, Oxford: University Press.

Zabawa M., 2009, My blogasek bierze udział w konQursie. Czy polskie blogi internetowe są pisane po polsku?, w: M. Filiciak i G. Ptaszek (red.), Komunikowanie (się) w mediach elektronicznych. Jezzyk, edukacja, semiotyka, Warszawa: WAiP, s. 60-78.

ŻMigrodZKi P., 2007, Z leksykograficznej listy nieobecności: przymiotnik ocenny, LingVaria, nr 2(4), s. 103-111.

\section{'Lubię to'. Neosemantisation of the Polish verb 'lubić' in the context of Facebook}

( su m mary)

With the appearance of the social networking service, Facebook, the notion of 'liking' has gained an additional meaning. The aim of this article is to discuss the phenomenon of neosemantisation of the verb 'lubić' ('like') in the Polish version of the website. The author distinguishes between three Facebook-specific meanings of this verb: 'to be fond of something', 'to be related to something' and 'to recommend something'. The discussion of the phenomenon of neosemantisation of the verb 'lubić' is accompanied by an analysis of its occurrences through the example of Facebook-related elements on websites of universities and colleges in Warsaw. 